\title{
ANALISIS KEMAMPUAN KERJA SEBAGAI VALUE DARI PENDIDIKAAN DAN PELATIHAN (Studi Pada Kantor Badan Kepegawaian Daerah Provinsi Bengkulu)
}

\author{
Slamet Widodo \\ Effed Darta Hadi \\ Program Studi Manajemen, Fakultas Ekonomi dan Bisnis, Universitas Bengkulu
}

\begin{abstract}
The purpose of this study is to determine the role of job training to improve knowledge, skills, attitudes and personality in carrying out the functions and responsibilities toward the achievement of organizational goals. The method used in this study is a survey by conducting in depth-interviews to the employees of the Regional Personnel Board of Bengkulu Province. The results of this study indicate that in particular training or training that has been followed by employees can improve knowledge, work skills, and understanding of their work. This is shown in the way the work and how to solve problems effectively that can be done by employees. Practically the results of this study revealed that an organization needs human resources that have a good individual capacity such as knowledge, skills and understanding in the work. The education and training programs followed by employees are believed to have benefited from individual capacity building and capability, thereby impacting on the quality of services provided.
\end{abstract}

Keywords: Training, knowledge, performance.

\section{PENDAHULUAN}

\section{Latar Belakang}

Sumber Daya Manusia (SDM) merupakan salah satu komponen dalam organisasi yang harus ada. Tujuan organisasi tidak akan tercapai tanpa adanya kombinasi dan kolaborasi yang baik dari orang-orang yang tergabung dalam organisasi tersebut. Biasanya, sumberdaya manusia di dalam organisasi disebut dengan karyawan atau pegawai. Karyawan atau pegawai dengan bakat, karya, kreativitas, dan kemampuan yang fleksibel sangat menentukan suksesnya pencapaian tujuan organisasi. Betapapun baik dan sempurnanya aspek teknologi, rencana kerja, dan peralatan kerja, jika tidak didukung oleh kemampuan karyawan (SDM) yang mampu mengaplikasikan dan menggunakan teknologi tersebut, maka sulit bagi suatu organisasi mencapai tujuan secara efektif dan efisien sesuai dengan standar yang diharapkan.

Sastrohadiwiryo (2001) menyatakan beberapa hal yang dilihat dalam kemampuan kerja pegawai yakni: kesetiaan, prestasi, tanggungjawab, ketaatan, kejujuran, kerjasama, prakarsa, dan kepemimpinan. Sedangkan Handoko (1998) menyatakan 
bahwa kemampuan kerja (kinerja) karyawan dapat dilihat dari sejauhmana karyawan dapat menyelesaikan pekerjaan sesuai dengan ketentuan organisasi.

Secara teori pembahasan mengenai faktor-faktor yang mempengaruhi kemampuan kerja sangatlah banyak. Vrom (dalam Mulyasa, 2005) menyatakan bahwa kemampuan merupakan fungsi dari pendidikan dan pelatihan. Sedangkan Mathis dan Jakson (2006) menyatakan bahwa kemampuan kerja karyawan dipengaruhi oleh: (a) faktor individual, seperti bakat, minat, faktor kepribadian), (b) dukungan organisasional seperti pelatihan dan pengembangan, peralatan dan teknologi, standar kerja, manajemen dan rekan kerja, dan (c) usaha yang dicurahkan seperti: motivasi, etika kerja, kehadiran, rancangan tugas dan persepsi peran.

Berdasarkan dua teori tersebut, pihak manajemen harus mampu membuat pegawai atau karyawan berupaya untuk selalu bekerja sebaik mungkin, berupaya hadir tepat waktu, berupaya menyelesaikan tugas tepat waktu, dan berupaya semaksimal mungkin dalam menggunakan segenap kemampuan yang dimilikinya untuk mencapai tujuan organisasi serta mampu memberikan pelayanan prima kepada masyarakat. Anoraga (1995) menyatakan bahwa tujuan organisasi sulit tercapai apabila karyawan tidak mau menggali potensi yang ada dalam dirinya untuk bekerja semaksimal mungkin. Upaya-upaya tersebut tentu saja harus didukung oleh kemampuan individu pegawai sendiri agar tugas-tugas yang menjadi tanggungjawabanya tersebut mampu diselesaikan dengan baik.

Guna meningkatkan kapasitas individu pegawai dalam memberikan pelayanan kepada pegawai dengan melaksanakan berbagai program pendidikan dan pelatihan kerja bagi pegawai, mulai program pelatihan pemahaman tugas pegawai, program pelatihan penggunaan peralatan kerja, dan program peningkatan pelayanan publik. Dampak dari pelaksanaan program pendidikan dan pelatihan diharapkan mampu meningkatkan kualitas profesionalisme dan mentalisme pegawai BKD Provinsi Bengkulu yang handal dalam rangka pelaksanaan tugas pemerintah, pembangunan, dan kemasyarakatan.

Arah dan kebijakan merupakan bagian dari upaya pencapaian visi, misi, sasaran dan tujuan yang telah di tuangkan dalam rencana strategis daerah Pemerintah yang di dukung oleh aparatur yang profesional dan berkualitas. Proses pelayanan di suatu daerah yang lain mempunyai pola tindak yang berbeda sesuai dengan kebijakan Kepala Daerah yang disesuaikan dengan kondisi di lingkungan masyarakat di daerah itu. Pelayanan di harapkan mampu untuk mempermudah pelayanan masyarakat dengan upaya memangkas sistem birokrasi yang kurang efektif menjadi lebih ringkas, mudah, dan terarah dengan baik.

Permasalahan kemampuan kerja pegawai sering sekali berkaitan dengan kurangnya pemahaman pegawai terhadap tugas, kemampuan pemahaman tersebut di peroleh dari latar belakang pegawai yang antara lain di lihat dari pendidikan, menyangkut pengetahuan, keterampilan, sikap dan kepribadian dalam menjalankan fungsi dan tanggung jawab terhadap pencapaian tujuan organisasi. Terkadang pegawai di bebani tugas yang tidak sesuai dengan latar belakang pendidikan dan keterampilan 
yang di miliki, dalam hal ini rutinitas kerja memang terlaksana akan tetapi hasil kerja tidak sesuai dengan yang di harapkan.

Badan Kepegawaian Daerah (BKD) Provinsi Bengkulu sangat membutuhkan sumber daya manusia yang profesional dalam pelayanan peningkatan pelayanan kepegawaian, mempunyai ide-ide yang kreatif dan inovatif yang mampu bekerja secara ulet, rajin, disiplin dan mampu mandiri untuk menjalankan tugas dan fungsinya.

\section{TINJAUAN PUSTAKA}

\section{Pengertian Pendidikan dan Pelatihan}

Menurut Hasibuan (1990:76) Pendidikan adalah segala usaha untuk membina kepribadian dan mengembangkan kemampuan manusia,jasmani dan rohani yang berlangsung seumur hidup, baik dalam maupun di luar sekolah, dalam rangka pembangunan persatuan dan masyarakat adil dan makmur, sementara itu menurut Mulyanto (1998:27) Pendidikan adalah suatu kegiatan untuk memperbaiki kemampuan pegawai dengan cara meningkatkan pengetahuan dan pengertian tentang pengetahuan umum, termasuk peningkatan penguasaan teori pengambilan keputusan dalam menghadapi persoalan-persoalan, keseluruhan proses terkait dengan metode belajar mengajar dalam rangka mentransfer suatu pengetahuan dari seseorang kepada orang lain sesuai dengan standar yang telah di tetapkan sebelumnya.

Dari definisi yang ada dapat diartikan bahwa pendidikan merupakan usaha sadar dalam membentuk kepribadian manusia melalui penguasaan pengetahuan, pola sikap dan pola tindak tertentu, sejalan dengan penguasaan pengetahuan itu sendiri yang memberikan pengaruh kepada individu dalam perkembangan jasmani dan rohani. Yuwono (1991:20) menjelaskan bagaimana pendidikan itu dapat mempengaruhi kemampuan seseorang (aparat), kemampuan seseorang yang dapat di peroleh dari pendidikan, karena pada dasrnya pendidikan mempunyai tujuan untuk membentuk kepribadian seseorang dalam berbagai aspek. Oleh karena itu pendidikan merupakan faktor yang mempunyai peranan penting dalam pembentukan perilaku dan kepribadian seorang baik sebagai makhluk individu maupun sebagai makhluk sosial. Melalui Pendidikan yang diperoleh di lembaga pendidikan formal terutama di perguruan tinggi, seseorang mempunyai kesempatan lebih banyak untuk memahami pembentukan prilaku dan kepribadian, selanjutnya perilaku dan kepribadian yang telah di bentuk menjadi modal bagi seseorang dalam kehidupan berorganisasi.

Pentingnya Pendidikan di jelaskan Riwukoho (1997:46) adalah memberikan pengetahuan yang luas dan mendalam tentang bidang yang di pilih atau dipelajari seseorang.

1. Melatih manusia untuk berfikir secara rasional dan menggunakan kecerdasan arah yang tepat, melatih manusia menggunakan akal dalam kehidupan sehari-hari dalam berfikir, menyatakan pendapat maupun bertindak. 
2. Memberikan kemampuan dan keterampilan kepada manusia untuk merumuskan pikiran, pendapat yang hendak di sampaikan kepada orang lain secara logis dan sistematis sehingga mudah di mengerti.

Melalui pendidikan maka akan menambah pengetahuan seseorang, membentuk kepribadian memiliki dan mengembangkan kemampuan berfikir, secara rasional, kemampuan analitik, serta berfikir secara ilmiah dan objektif, sehingga dapat dikatakan semakin tinggi pula kemampuannya. Oleh karena itu tingkat pendidikan (formal) dapat di gunakan sebagai salah satu indikator untuk mengetahui tingkat kemampuan seseorang (aparatur).

Sedangkan pelatihan Hendry Simamora (1995:286) adalah merupakan penciptaan suatu lingkungan di mana para karyawan dapat memperoleh atau mempelajari sikap, kemampuan, keahlian, pengetahuan dan perilaku yang spesifik yang berkaitan dengan pekerjaan. Menurut Handoko (1998: 32) pelatihan di tujukan untuk memperbaiki penguasaan berbagai keterampilan dan teknik pelaksanaan kerja dalam jabatannya. Pelatihan akan membentuk dasar dengan menambah keterampilan dan pengetahuan yang di perlukan untuk memperbaiki prestasi dalam jabatan yang sekarang atau mengembangkan potensinya untuk masa yang akan datang.

Dari definisi tersebut dapat diketahui bahwa pelatihan adalah suatu proses yang akan menghasilkan suatu perubahan prilaku yang berbentuk peningkatan kemampuan. Pelatihan pada umumnya menekankan kepada kemampuan psikomotor, meskipun di dasari pengetahuan dan sikap.

Pentingnya pendidikan dan pelatihan seperti di uraikan di atas, tidak hanya berdampak bagi pegawai saja akan tetapi juga pada keuntungan suatu organisasi dan lembaga. Dengan meningkatnya kemampuan dan keterampilan para pegawai, maka meningkat juga produktivitas kerja baik secara kualitas maupun kuantitas, menaikkan stabilitas dan fleksibilitas tenaga kerja, menaikkan moral kerja dan mengembangkan pertumbuhan pribadi.

Berdasarkan beberapa definisi di atas, maka dapat di simpulkan bahwa pendidikan pada umumnya berkaitan dengan mempersiapkan calon tenaga yang di perlukan oleh suatu instansi atau organisasi. Sedangkan pelatihan lebih berkaitan dengan peningkatan kemampuan atau keterampilan pegawai yang sudah menduduki suatu jabatan pekerjaan. Oleh karena itu orientasinya kepada pelaksanaan tugas serta kemampuan khusus pada sasaran, maka jangka waktu pelatihan pada umumnya lebih pendek dari pada pendidikan. Demikian pula metode belajar mengajar yang di gunakan pada pelatihan lebih inovatif di banding dengan pendidikan. Pada akhir suatu proses pelatihan biasanya peserta hanya memperoleh suatu sertifikat, sedangkan pendidikan peserta pada umumnya memperoleh ijazah atau gelar.

\section{Manfaat Diklat terhadap Peningkatan Kemampuan Kerja Pegawai}


Pelatihan sebagai sarana motivasi yang mendorong para karyawan untuk bekerja dengan kemampuan yang optimal, yang dimaksudkan untuk meningkatkan performa dari karyawan tersebut. Pemberian pelatihan dimaksudkan agar dapat memenuhi standar kerja yang telah ditetapkan oleh perusahaan. Pelatihan dapat diartikan sebagai suatu usaha yang terencana untuk memfasilitasi pembelajaran tentang pekerjaan yang berkaitan dengan pengetahuan, keahlian dan perilaku oleh para pegawai.

Menurut Mathis dan Jackson (2006:301), "Pelatihan adalah suatu proses dimana orang-orang mencapai kemampuan tertentu untuk membantu mencapai tujuan organisasi". Oleh karena itu, proses ini terikat dengan berbagai tujuan organisasi, pelatihan dapat dipandang secara sempit maupun luas. Secara terbatas, pelatihan menyediakan para pegawai dengan pengetahuan yang spesifik dan dapat diketahui serta keterampilan yang digunakan dalam pekerjaan mereka saat ini.

Pelatihan menurut Dessler (2010:280) adalah "Proses mengajarkan karyawan baru atau yang ada sekarang, ketrampilan dasar yang mereka butuhkan untuk menjalankan pekerjaan mereka". Pelatihan merupakan salah satu usaha dalam meningkatkan mutu sumber daya manusia dalam dunia kerja. Karyawan yang baru ataupun yang sudah bekerja perlu mengikuti pelatihan karena adanya tuntutan pekerjaan yang dapat berubah akibat perubahan lingkungan kerja, strategi, dan lain sebagainya.

Pelatihan berpengaruh signifikan terhadap kemampuan. Hal ini menunjukkan bahwa pelatihan akan memberikan kesempatan bagi karyawan mengembangkan keahlian dan kemampuan baru dalam bekerja agar apa yang diketahui dan dikuasai saat ini maupun untuk masa mendatang dapat membantu karyawan untuk mengerti apa yang seharusnya dikerjakan dan memberikan kesempatan untuk menambah pengetahuan dan keahlian. Hal ini menunjukan bahwa pelatihan sangat bermanfaat untuk perusahaan dan karyawanya itu sendiri. Menurut Atmodiwirio (2005:74), bahwa manfaat pelatihan dapat dilihat dari dua sisi yaitu:

a. Sisi individu

1) Menambah wawasan, pengetahuan tentang perkembangan organisasi baik secara internal ataupun eksternal.

2) Menambah pengetahuan di bidang tugasnya.

3) Menambah keterampilan dalam meningkatkan pelaksanaan tugasnya.

4) Meningkatkan pengalaman memimpin.

5) Meningkatkan kemampuan menangani emosi.

b. Sisi Organisasi

1) Meningkatkan kemampuan berproduksi.

2) Penyesuaian terhadap perubahan yang terjadi di lingkungannya.

3) Meningkatkan kemampuan organisasi untuk menciptakan kolaborasi dan jejaring kerja. 


\section{Pengertian Kemampuan Kerja}

Perencanaan dan peningkatan kemampuan adalah suatu kondisi yang menunjukkan adanya peningkatan-peningkatan seseorang dalam suatu organisasi (Martoyo, 1998:70). Kemampuan pada dasarnya berorientasi pada perkembangan organisasi di masa mendatang. Setiap organisasi tanpa memiliki sumber daya manusia yang kompetitif akan mengalami kemunduran yang akhirnya dapat tersisih karena ketidakmampuannya menghadapi pesaingnya. Ada beberapa pengertian tentang kemampuan, menurut Flipo dan Martoyo (1998: 45) kemampuan adalah tingkat kemampuan seorang pegawai dalam rangka menyelesaikan pekerjaan yang diembankan kepadanya serta kemampuan seseorang dalam melaksanakan tugas sesuai dengan bidangnya masing-masing di tunjang oleh faktor-faktor pendidikan dan pengalaman.

Schermerhorn (1994: 113) memberikan definisi kemampuan adalah kemampuan seseorang dalam mempelajari sesuatu untuk dapat melaksanakan berbagai tugas yang di berikan, untuk pekerjaan yang diberikan, untuk pekerjaan yang di tetapkan. Sedangkan Robbins (2001:37) menyebut kemampuan adalah ability yaitu kapasitas seseorang individu untuk mengerjakan berbagai tugas dalam suatu pekerjaan. Selanjutnya di katakan bahwa kemampuan individu di bentuk dari dua perangkat faktor yaitu: faktor kemampuan intelektual dan faktor kemampuan fisik. Kemampuan intelektual adalah kemampuan yang di perlukan untuk melakukan kegiatan mental sedangkan kemampuan fisik adalah kemampuan yang di perlukan untuk melakukan tugas-tugas yang menuntut stamina, kecekatan, kekuatan dan keterampilan.

Berdasarkan pengertian di atas, kemampuan kerja merupakan faktor penentu kualitas manajemen sumber daya manusia pada dasarnya bertujuan untuk memperbaiki dan meningkatkan efektivitas pekerja, agar semakin mampu memberikan yang terbaik dan mewujudkan tujuan organisasi. Faktor yang mempengaruhi pencapaian kerja salah satunya adalah faktor kemampuan kerja yang di pengaruhi oleh faktor internal seperti pengetahuan kerja, keterampilan kerja dan pemahaman karyawan terhadap pekerjaan.

\section{Pengetahuan Kerja}

Pengertian antara ilmu pengetahuan dan pengetahuan sering kali kabur. Tapi, umumnya di kalangan ilmuwan maupun para pilsuf terhadap kesepakatan bahwa ilmu adalah sesuatu kumpulan pengetahuan sistematis, Demikian lazim perumusan itu sehingga pengertian ilmu sebagai aktivitas dan metode tampak terselubung dan kurang dikenal. Gie (2000: 120) pengetahuan pada dasarnya adalah keseluruhan keterangan, ide yang terkandung dalam pernyataan - pernyataan yang di buat mengenai sesuatu gejala/peristiwa baik yang bersifat ilmiah atau sosial maupun perorangan. Jadi, pengetahuan menunjuk kepada sesuatu yang merupakan isi substantif yang terkandung dalam ilmu. Lebih lanjut Gie mengartikan pengetahuan sebagai keseluruhan faktor-faktor keterangan dan azas yang di peroleh seseorang melalui proses belajar dan pengalaman. Dari rumusan tersebut, sumber-sumber pengetahuan di peroleh dari hasil telah (study learning) dan pengetahuan (experience) ilham (ituition) juga dapat menjadi sumber dari pengetahuan. 
Sofo (1999: 78) mengartikan pengetahuan sebagai kemampuan untuk menyelesaikan tugas tertentu melalui belajar. Belajar adalah mengaitkan secara bersama-sama antara data dengan informasi, pengalaman dan sikap yang dimiliki seseorang sebagai contohnya adalah menjadi bisa berenang atau membersihkan kaca jendela yang pecah. Dari rumusan tersebut, pengetahuan kerja dapat diartikan sebagai kemampuan untuk menyelesaikan tugas tertentu melalui belajar yang bersumber dari hasil telaah, pengalaman dan informasi.

\section{Keterampilan kerja}

Robbins (2001: 481) mengatakan persaingan makin ketat, perubahan tehnologi dan upaya meningkatkan produktivitas memotivasi manajemen untuk menaikkan pengeluaran bagi pelatihan. Melalui pelatihan akan diperoleh keterampilan yang diinginkan sehingga dapat gilirannya akan menuju kepada peningkatan produktivitas atau kemampuan kerja. Dalam penggunaan sehari-hari sering kata keterampilan diganti dengan skill. Kata skill yang mengandung arti sama dengan keterampilan ini seolah-olah sudah menjadi bagian dari perbendaharaan kata bahasa Indonesia. Spencer and Spencer (1993:11) mengatakan bahwa keterampilan merupakan kemampuan seseorang untuk melakukan sesuatu pekerjaan fisik maupun mental.

Scehermerhorn (1994:24) memberikan definisi skill adalah sebagai kemampuan menggunakan pengetahuan dalam tindakan yang menghasilkan kemampuan kerja/kinerja yang diinginkan. Kemampuan ini memungkinkan seseorang untuk mencapai kinerja tinggi dalam bidang pekerjaannya. Katz dalam Schermerhorn (1994: 24) membagi skill dalam tiga kategori yaitu kemampuan untuk melaksanakan tugas khusus, kemampuan untuk bekerja secara baik dengan orang lain dan kemampuan untuk menganalisis dan menyelesaikan masalah yang rumit. Hal yang sama juga di kemukakan oleh Hersey dan Blanchard (1980:6) tentang tiga keterampilan yang di perlukan untuk melaksanakan proses manajemen yaitu:

1. Technical Skill, yaitu merupakan kemampuan untuk menggunakan pengetahuan, metode, teknik dan peralatan yang di butuhkan oleh kinerja tugas-tugas yang di peroleh dari pengalaman, pendidikan dan pelatihan.

2. Human Skill, yaitu kemampuan dan penelitian dalam bekerja sama dengan dan melalui orang lain, termasuk memahami motivasi dan penerapan kepemimpinan efektif.

3. Conceptual Skill, yaitu kemampuan untuk memahami kompleksitas keseluruhan organisasi dan kecocokan suatu operasi tertentu ke dalam organisasi. Pengetahuan ini memungkinkan seseorang untuk bertindak sesuai dengan tujuan organisasi secara keseluruhan ketimbang hanya berdasarkan tujuan dan kebutuhan individu atau kelompok tertentu.

Robbins (2003: 75) mengatakan bahwa istilah keterampilan (skill) merujuk kepada kemampuan dari seseorang untuk melakukan berbagai jenis kegiatan kognitif atau perilaku (Behavior) dengan suatu cara yang efektif. 
Megginson (1999: 171) mendefinisikan skill sebagai kemampuan untuk menghasilkan efek yang di kehendaki secara konsisten, biasanya berhubungan dengan bentuk khusus hasil karya seseorang. Menurut Robbins (2003: 264- 246) keterampilan dapat di bagi dalam 3 (tiga) kategori yaitu:

1. Teknis, yaitu kebanyakan pelatihan di arahkan untuk menata dan memperbaiki keterampilan teknis pegawai. Pelatihan teknis telah menjadi semakin penting dewasa ini dua alasan tehnologi baru dan rancangan struktur baru. Selain itu, pelatihan teknis telah menjadi semakin penting karena perubahan dalam rancangan organisasi. Ketika organisasi mendatarkan strukturnya, memperluas penggunaan tim dan menguraikan halaman-halaman departemen tradisional, karyawan perlu mempelajari berbagai tugas yang lebih luas.

2. Hubungan antar pribadi, pada tingkat tertentu kemampuan kerja tergantung pada kemampuan berinteraksi secara efektif dengan rekan sekerja dan atasan mereka. Beberapa pegawai mempunyai keterampilan hubungan antar pribadi yang unggul, tetapi yang lain membutuhkan pelatihan untuk memperbaiki keterampilan itu. Ini mencakup bagaimana menjadi pendengar yang lebih baik, bagaimana mengkomunikasikan gagasan lebih jelas dan bagaimana dapat menjadi pemain inti yang lebih efektif.

3. Pemecahan masalah, apabila orang-orang menuntut keterampilan, tetapi keterampilan ini kurang memadai, maka mereka dapat ambil bagian dalam pelatihan pemecahan masalah. Ini akan mencakup kegiatan mempertajam logika, penalaran dan keterampilan mendefinisikan masalah, maupun kemampuan mereka mereka menilai sebab akibat, mengembangkan alternatif, menganalisis alternatif dan memilih pemecahan.

Kazuo (1996: 49) mengatakan bahwa keterampilan terbentuk karena pengalaman juga melalui kerja praktek. Orang Jepang percaya bahwa pekerja Amerika memperoleh keterampilan karena berpindah-pindah kerja dari perusahaan satu ke perusahaan lainnya atau belajar melalui pusat training di luar perusahaan. Bentuk keterampilan tergantung dari industrinya. Kazuo juga membagi keterampilan menjadi empat yaitu: 1) Keterampilan tinggi seperti memahat, 2) keterampilan rendah seperti buruh, 3) keterampilan tinggi karena selalu di tingkatkan setiap waktu dan 4) keterampilan yang perkembangannya lambat.

Dari berbagai pendapat di atas dapat di simpulkan bahwa keterampilan (skill) adalah kemampuan seseorang yang tercantum dari perilaku kerjanya yang di peroleh melalui pengalaman atau belajar dan berguna bagi pelaksanaan tugas untuk menyelesaikan masalah guna peningkatan kemampuan kerja atau efisiensi. Oleh karena itu keterampilan yang di peroleh melalui belajar di gunakan untuk meningkatkan keterampilan dan pengetahuan dan mewakili perilaku kerja yang luas yang perlu dipelajari.

\section{Pemahaman Kerja}

Pemahaman merupakan suatu kondisi dalam diri individu yang mendorong, mengarahkan serta menentukan hasil yang di oeroleh dalam mencapai tujuan untuk 
serangkaian kegiatan yang di lakukan. Dalam aktivitasnya itu terdapat suatu proses psikologis yang dapat menetukan intensitas perbuatan tersebut.Spencer dan Spencer (1993:9) menjelaskan bahwa pemahaman adalah sesuatu yang konsisten dipikirkan atau diinginkan sehingga menyebabkan suatu tindakan. Pemahaman akan mendorong, mengarahkan perilaku terhadap tindakan tau tujuan tertentu dan tidak pada yang lainnya.

Pemahaman pegawai terhadap pekerjaan akan memberikan kemampuan bagi pegawai terutama kemampuan dalam menjabarkan tugas pokok dan funsinya yang terbentuk dalam struktur organisasi.Tugas pokok dan fungsi organisasi dijabarkan dalam kerjasama kelembagaan, sedangkan hubungan kerja yang terbentuk meliputi pelaksanaan tugas (Martoyo, 1990). Indikator pemahaman Jika merujuk pada kepada beberapa definisi di atas dan dikaitkan dengan kepegawaian antara lain, mampu menjabarkan tugas dan fungsinya sebagai pegawai, mampu bekerja sama dengan baik antar sesama pegawai dan mampu merealisasikan pengetahuannya dalam bentuk yang lebih praktis sehingga menghasilkan kerja yang lebih baik sesuai dengan target kerja yang telah ditentukan. Dari definisi di atas, dapat diartikan bahwa, pemahaman pegawai terhadap pekerjaan merupakan sikap yang selalu siap untuk merespon pekerjaan secara objektif dan konsisten. Sikap terhadap objek tertentu yang dapat merupakan sikap pandangan atau sikap perasaan, tetapi sikap tersebut disertai oleh kecenderungan untuk bertindak yang di dukung oleh pengetahuan kerja dan keterampilan kerja

\section{Kerangka Analisis Penelitian}

Kerangka analisis penelitian ini adalah menguraikan manfaat pendidikan dan pelatihan pada peningkatan kemampuan kerja pegawai.

\section{Gambar 1 \\ Kerangka Analisis}

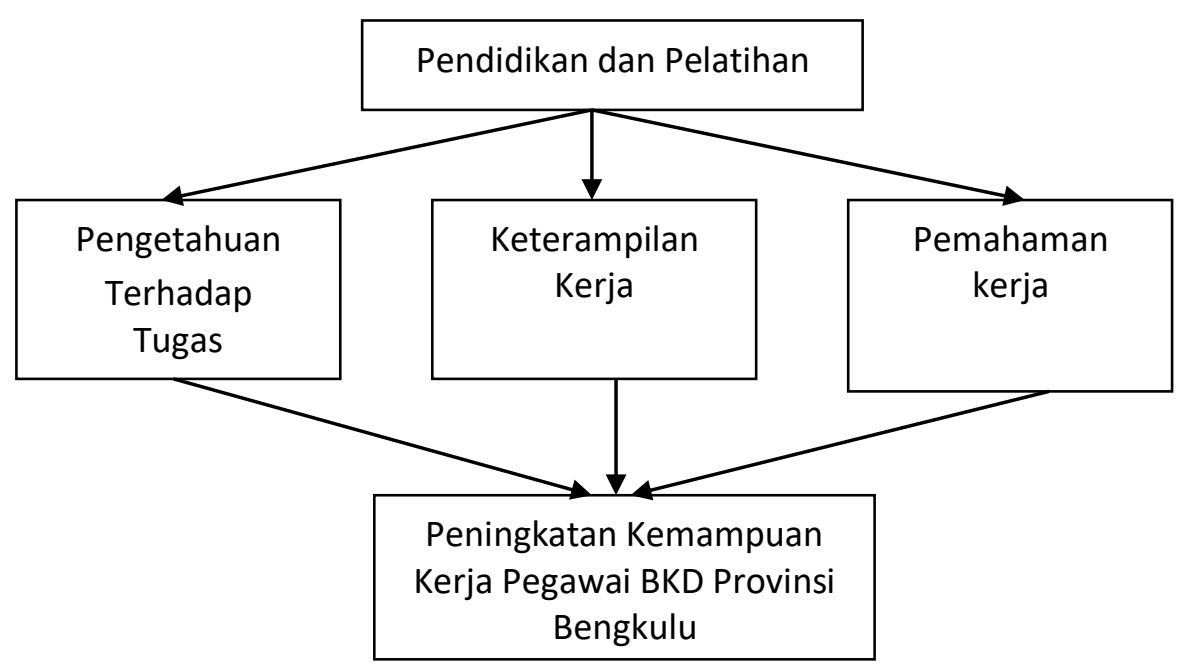

Study deskriptif kualitatif pada Kantor Badan Kepegawaian Daerah (BKD) Provinsi Bengkulu. Indikator kemampuan kerja pegawai pada penelitian ini mengacu pada pengetahuan kerja, keterampilan kerja dan pemahaman pegawai terhadap 
pekerjaan. Secara sistematis, kerangka permasalahan yang akan di bahas dalam penelitian ini dapat di lihat pada Gambar 1.

\section{Jenis Penelitian}

\section{METODE PENELITIAN}

Dalam rangka memperoleh jawaban terhadap permasalahan-permasalahan, maka dalam penelitian ini menggunakan metode deskriptif kualitatif. Menurut Moeleong (2002) penelitian kualitatif berakar pada latar ilmiah sebagai keutuhan yang mengandalkan manusia sebagai alat penelitian. Sedangkan menurut Maman (2002: 3) penelitian deskriptif berusaha menggambarkan suatu gejala sosial. Penelitian ini bertujuan untuk menganalisa manfaat pendidikan dan pelatihan pada peningkatan kemampuan kerja pegawai Badan Kepegawaian Daerah (BKD) Provinsi Bengkulu.

Penelitian deskriptif kualitatif di sini berusaha untuk dapat mendeskripsikan secara lengkap manfaat pendidikan dan pelatihan pada peningkatan kemampuan kerja pegawai dengan indikator kemampuan pegawai di tinjau dari pengetahuan kerja, keterampilan kerja dan pemahaman pegawai itu sendiri.

Penelitian ini dapat di kategorikan dalam jenis penelitian kualitatif, karena data akan di gali secara mendalam tidak hanya sebatas angka-angka numerik, akan tetapi berusaha menggali makna dari fenomena dan keadaan supaya dapat dideskripsikan dengan jelas.

\section{Jenis dan Sumber Data}

Data yang digunakan dalam penelitian ini adalah data primer. Menurut Sugiyono (2010) data primer adalah data-data yang diperoleh secara langsung dari sumbernya, yaitu para responden berupa tanggapan-tanggapan mereka terhadap item-item instrumen penelitian yang diperoleh melalui penyebaran kuesioner, wawancara, dan pengamatan lapangan.

\section{Metode Pengumpulan Data}

Data-data yang diperoleh dalam penelitian diambil dengan menggunakan tiga teknik pengumpulan data yaitu:

\section{a. Penyebaran Kuesioner}

Penyebaran kuesioner dilakukan sebagai alat pengumpulan data utama. Dalam kuesioner tersebut berisi pertanyaan-pertanyaan terkait dengan variabel pemberdayaan peawai beserta sub-variabelnya. Agar memudahkan responden dalam memberikan jawaban, pertanyaan-pertanyaan yang ada di dalam kuesioner disertai dengan pilihan jawaban menggunakan skala likert.

\section{b. Wawancara (Interview)}

Wawancara (interview) yaitu cara pengumpulan data dengan langsung mengadakan tanya jawab kepada objek yang diteliti atau kepada perantara yang mengetahui persoalan dari objek yang diteliti. Ciri utama dari interview adalah kontak langsung dengan tatap muka antar pencari informasi (interviewer) dan sumber informasi. Teknik ini diperlukan untuk menggali dan memperoleh informasi yang lebih mendalam tentang pendapat pegawai mengenai program pengembangan karier di dalam organisasinya.

\section{c. Pengamatan (Observasi)}


Pengamatan (observasi) yaitu pengumpulan data dengan turun dan melihat langsung ke lapangan. Observasi diartikan sebagai pengamatan dan pencatatan secara sistematik terhadap gejala yang tampak pada objek penelitian. Seperti diungkapkan Moleong (2001) bahwa teknik observasi terdiri dari dua yaitu observasi langsung yaitu pengamatan dan pencatatan dilakukan terhadap objek ditempat terjadi atau berlangsungnya peristiwa sehingga observasi berada bersama objek yang dimiliki, dan observasi tidak langsung yaitu pengamatan yang dilakukan tidak pada saat berlangsung nya suatu peristiwa yang akan diselidiki, misalnya peristiwa yang diamati melalui film, rangkaian slide, atau rangkaian foto, selanjutnya penggunaan teknik menurut Arikunto (2002) bahwa penggunaan metode observasi cara yang paling efektif adalah melengkapinya dengan format atau blangko pengamatan sebagai instrument.

Artinya peneliti dalam penggunaan teknik observasi cara yang efektif adalah dengan dilengkapi dengan adanya format atau blangko pengamatan dipakai sebagai instrument untuk mendapatkan informasi objek penelitian. Teknik observasi juga dijelaskan Surakhmad (1980), observasi adalah teknik pengumpulan data dimana penyelidik mengadakan pengamatan secara langsung terhadap gejala gejala subjek yang diselidiki, baik pengamatan itu dilakukan dalam situasi yang sebenarnya maupun dilakukan didalam situasi buatan yang khusus diadakan. Untuk penelitian ini pengamatan dilakukan untuk melihat kondisi pegawai di lokasi penelitian dengan sebenarnya.

\section{Teknik Pengambilan Sampel}

Subjek utama penelitian ini adalah pegawai BKD Provinsi Bengkulu yang telah mendapatkan pendidikan dan pelatihan (diklat). Adapun data pegawai Badan Kepegawaian Daerah (BKD) Provinsi Bengkulu sebagai berikut:

Tabel 2. Populasi dan Sampel

\begin{tabular}{|l|l|l|l|l|}
\hline No & Keterangan & $\begin{array}{l}\text { Populasi } \\
\text { (Orang) }\end{array}$ & $\begin{array}{l}\text { Sampel } \\
\text { (Orang) }\end{array}$ & $\begin{array}{l}\text { Subjek } \\
\text { Wawancara }\end{array}$ \\
\hline 1 & Kepala Badan & 1 & - & - \\
\hline 2 & Sekretariat & 22 & 22 & 2 \\
\hline 3 & Bidang Pengembangan Karir & 14 & 14 & 2 \\
\hline 4 & $\begin{array}{l}\text { Bidang Informasi dan } \\
\text { Peningkatan Kualitas Pegawai }\end{array}$ & 12 & 12 & 2 \\
\hline 5 & $\begin{array}{l}\text { Bidang Jabatan Fungsional dan } \\
\text { Kesejahteraan }\end{array}$ & 14 & 14 & 2 \\
\hline 6 & $\begin{array}{l}\text { Bidang Mutasi dan Kedudukan } \\
\text { Hukum }\end{array}$ & 14 & 14 & 2 \\
\hline & Jumlah & $\mathbf{7 7}$ & $\mathbf{7 6}$ & $\mathbf{1 0}$ \\
\hline
\end{tabular}

Sumber: BKD Provinsi Bengkulu, 2015

Jumlah sampel penelitian yang akan diambil seluruh pegawai BKD Provinsi Bengkulu yang berjumlah 76 orang (tidak termasuk kepala badan) yang diambil dengan teknik sensus. Untuk subjek wawancara diambil sebanyak 10 orang dengan metode purposive sampling.

\section{HASIL PENELITIAN DAN PEMBAHASAN}

\section{Analisis Statistika Deskriptif}




\section{Karakteristik Responden}

Responden dalam penelitian ini berjumlah 76 orang pegawai Badan Kepegawaian Daerah Provinsi Bengkulu. Responden tersebut diambil dengan menggunakan teknis sensus. Keadaan pegawai Badan Kepegawaian Daerah Provinsi Bengkulu berdasarkan tingkat pendidikannya dapat akan disajikan pada tabel berikut:

Tabel 4.1 Karakteristik Responden

\begin{tabular}{|r|l|l|c|}
\hline No & Karakteristik Responden & $\begin{array}{c}\text { Jumlah } \\
\text { (Orang) }\end{array}$ & $\begin{array}{c}\text { Persentase } \\
\text { (\%) }\end{array}$ \\
\hline & Tingkat Pendidikan & & \\
1 & Pascasarjana & 20 & 26,32 \\
2 & Sarjana & 42 & 55,26 \\
3 & Sarjana Muda & & 18,42 \\
\hline & Pangkat/Golongan & 10 & 13,16 \\
1 & II & 54 & 71,05 \\
2 & III & 12 & 15,79 \\
3 & IV & 1 & 1,32 \\
\hline & Masa Kerja & 6,58 \\
2 & < T Tahun & 5 & 44,74 \\
3 & 5 - 10 Tahun & 34 & 47,37 \\
4 & $>15$ Tahun & 36 & $\mathbf{1 0 0 , 0 0}$ \\
\hline JUMLAH & $\mathbf{7 6}$ & \\
\hline
\end{tabular}

Sumber Data : Badan Kepegawaian Daerah Provinsi Bengkulu, 2015

Pegawai Badan Kepegawaian Daerah Provinsi Bengkulu sebanyak 76 orang yang terdiri dari 43 orang pegawai laki-laki dan 33 orang pegawai perempuan. Seluruh pegawai Badan Kepegawaian Daerah Provinsi Bengkulu memiliki tingkat pendidikan yang baik dan memadai karena mayoritas pegawai telah berpendidikan sarjana. Tingkat pendidikan yang baik dan memadai akan menentukan keberhasilan pegawai dalam melaksanakan tugas memberikan pelayanan kepada masyarakat.

Selanjutnya, dari Tabel 4.1 juga dapat diketahui bahwa rata-rata pegawai memiliki golongan III. Hal ini menunjukkan bahwa pengalaman kerja yang baik, sehingga memungkinkan pegawai dapat melaksanakan tugas dan kewajibannya dengan baik. Kemudian masa kerja pegawai Badan Kepegawaian Daerah Provinsi Bengkulu sangat bervariasi. Mayoritas pegawai BKD telah memiliki masa kerja terlama yakni di atas 15 tahun yaitu dan terendah di bawah 5 tahun. Ini membuktikan bahwa sebagian besar pegawai yang ada sudah mengabdi cukup lama di jajaran pemerintahan daerah, khususnya dalam lingkungan Badan Kepegawaian Daerah Provinsi Bengkulu. Hal ini menunjukkan bahwa para pegawai sudah memiliki cukup banyak pengalaman dalam bidang pemerintahan yang dapat mempengaruhi kinerjanya dalam menyelesaikan tugas yang diberikan, termasuk dalam memberikan layanan kepada masyarakat.

\section{Manfaat Diklat dalam Meningkatkakan Kemampuan Kerja Pegawai}


Pendidikan dan pelatihan (Diklat) adalah program yang dirancang untuk pengembangan sumber daya manusia (SDM), meliputi pengembangan aspek kemampuan intelektual (knowledge) maupun kepribadian (personality) pegawai. Menurut Ndraha (2001) pendidikan lebih difokuskan pada proses pembentukan kepribadian yang menyangkut cipta, rasa, karsa, dan kepribadian. Sedangkan pelatihan lebih difokuskan pada aspek kemampuan teknis. Dari sudut pandang jabatan, maka pendidikan dan pelatihan bertujuan untuk mentransfer, membentuk, dan menanamkan tiga komponen nilai: knowledge (pengetahuan), kemampuan teknis (technical ability), dan nilai perilaku (behavior). Dengan demikian pendidikan dan pelatihan akan dapat memberikan manfaat terhadap pelaksanaan tugas-tugas pegawai.

\section{PEMBAHASAN}

Hasil penelitian pada Badan Kepegawaian Daerah Provinsi Bengkulu diketahui bahwa pendidikan dan pelatihan yang diselenggarakan memberikan beberapa manfaat seperti peningkatan pengetahuan pegawai, peningkatan keterampilan pegawai dan peningkatan pemahaman kerja pegawai. Hasil-hasil penelitian tersebut selanjutnya diuraikan berikut ini.

\section{Peningkatan Pengetahuan Kerja Pegawai}

Pengetahuan kerja merupakan aspek penting dalam menunjang keberhasilan pegawai melaksanakan tugas pokok dan fungsinya. Pengetahuan kerja merupakan kemampuan seorang pegawai atau karyawan yang terbentuk dari proses belajar terus-menerus sehingga mampu memahami seluk-beluk pekerjaan yang digelutinya dengan baik. Seorang pegawai atau karyawan yang memiliki pengetahuan kerja yang baik, maka akan memiliki wawasasan berfikir, penguasaan konsep, penguasaan pekerjaan, profesionalisme, dan kapasitas diri yang semakin meningkat. Berdasarkan hasil penelitian dan petikan wawancara, mengindikasikan bahwa diklat yang diikuti oleh pegawai telah dapat memberikan tambahan wawasan berfikir pegawai sehingga pegawai dapat memahami dengan baik pekerjaanpekerjaan yang digelutinya. Hal ini disebabkan karena materi diklat disampaikan bukan hanya berupa teori saja, melainkan melakukan praktik langsung, sehingga kedua cara ini dianggap efektif dalam meningkatkan pengetahuan kerja pegawai.

Wawasan berfikir merupakan satu pandangan dan pemikiran seorang pegawai terhadap hal-hal tertentu yang bersifat dinamis, artinya setiap saat selalu berubah. Jika perubahan tersebut bersifat positif maka kan berdampak pada luasnya 
wawasan ada di dalam diri pegawai tersebut sehingga mampu menerima perubahan-perubahan yang ada di lingkungan sekitarnya. Sebaliknya, jika bersifat negatif, maka akan cenderung membuat pegawai berfikir sempit dan berwawasan dangkal, sehingga sulit akan menerima perubahan-perubahan yang terjadi.

\section{Peningkatan Penguasaan Konsep Pegawai}

Diklat yang diikuti oleh pegawai juga telah dapat memberikan tambahan wawasan konseptual pegawai dalam pemahaman pekerjaan-pekerjaan yang menjadi tanggungjawabnya. Wawasan konseptual merupakan landasan yang sangat penting, karena permasalahan-permasalahan pekerjaan dapat diketahui setelah melakukan telaah dan kajian secara komprehensif baik secara teori maupun praktek, sehingga diperoleh suatu penyelesaian yang tepat dan sesuai.

Dalam pengertian lain, bahwa meningkatnya wawasan konseptual pegawai akan membantu pegawai tersebut memahami dengan baik sendi-sendi pekerjaan mulai dari dasar hukum dan sistematika kerja sehingga akan terhindar dari penyimpangan-penyimpangan dalam pelaksanaannya. Dengan semakin minimalnya kesalahan yang terjadi maka risiko kerugian yang akan ditimbulkan dari suatu pekerjaan juga semakin kecil bahkan dalam kondisi yang sempurna, kesalahan menjadi nihil.

\section{Peningkatan Pengetahuan tentang Pekerjaan Pegawai}

Dari hasil petikan wawancara dengan pegawai dan atasan di atas, diketahui bahwa diklat yang diikuti oleh pegawai telah dapat memberikan tambahan pemahaman kepada pegawai terhadap tugas-tugasnya. Semakin tingginya pengetahuan pegawai akan tugas-tugasnya memungkinan pegawai dapat menyelesaikannya dengan baik pula. Dalam makna lain bahwa meningkatnya pengetahuan pegawai tentang pekerjannya terutama berkaitan dengan pelayanan kepada masyarakat akan membantu pegawai tersebut memahami dengan baik standar dan metode-metode penyelesaiannya, sehingga akan mampu menciptakan kinerja pelayanan yang baik pula dan mampu memberikan kepuasan kepada masyarakat (investor) yang dilayani.

\section{Peningkatan Pengetahuan dalam Penyelesaian Pekerjaan Pegawai}

Dari hasil wawancara dengan pegawai dan atasan, diketahui bahwa diklat yang diikuti oleh pegawai telah dapat memberikan manfaat terhadap pengetahuan pegawai dalam bekerja sehingga dapat menyelesaikannya dengan baik. Selain itu, menurut atasan, pegawai yang telah mengikuti diklat memiliki kemandirian kerja yang baik, sehingga intervensi atasan 
terhadap pelaksanaan tugas menjadi kecil. Saat ini pimpinan hanya melakukan advisory terhadap tugas-tugas bawahan.

\section{Peningkatan Kapasitas Individu Pegawai}

Diklat yang diikuti oleh pegawai telah dapat memberikan manfaat yang besar terhadap peningkatan kapasitas individu pegawai. Pegawai-pegawai yang telah mengikuti diklat memiliki kemampuan yang sangat baik dan professional dalam pekerjannya. Selain itu, pegawai juga memiliki kreativitas yang baik dan sangat mandiri sehingga menurunkan tingkat intervensi atasan dan rekan kerja lainnya dalam penyelesaian tugas-tugas pegawai.

\section{KESIMPULAN}

Berdasarkan hasil penelitian diketahui bahwa pendidikan dan pelatihan (diklat) yang diselenggarakan pada Badan Kepegawaian Daerah Provinsi Bengkulu telah dapat membantu pegawai dalam memahami pekerjaan, keterampilan dan pengetahuannya secara umum. Dengan adanya diklat tersebut pegawai yang tadinya tidak bisa menjadi bisa, yang tadinya sedikit bisa menjadi menguasai, dan dari yang tadinya sudah menguasai menjadi mahir.

\section{Manfaat Diklat Dalam Peningkatan Pengetahuan Kerja Pegawai}

Pendidikan dan pelatihan yang dilakukan biasanya bersifat teori dan praktik sehingga diyakini orang yang mengikuti pelatihan akan memiliki pemahaman teori dan praktik yang baik. Sebagaimana pendapat Ranupandoyo dan Husnan (2010) yang menjelaskan, bahwa pendidikan adalah suatu bentuk kegiatan yang ditujukan untuk meningkatkan pengetahuan seseorang termasuk teoritis maupun teknis. Sedangkan pelatihan dimaksudkan untuk meningkatkan keterampilan pegawai dalam pengetahuan yang bersifat praktis.

Secara umum, tujuan dilaksanakannya pendidikan dan pelatihan adalah untuk membantu pegawai agar lebih mudah, lebih cepat, dan lebih baik dalam melaksanakan tugasnya. Pegawai yang mendapatkan pendidikan dan pelatihan diharapkan melakukan kesalahan (error) yang lebih sedikit dibandingkan dengan yang belum. Tingkat kesalahan (error) kecil dapat mengurangi biaya, menghindari kerusakan yang tidak perlu/belum waktunya, dan menghindarkan kecelakaan kerja. Dalam hubungannya dengan pencapaian misi organisasi, maka pendidikan dan pelatihan kepemimpinan (Diklat kepemimpinan) dapat mengurangi kesalahan dalam tugas sekaligus juga meningkatkan kinerja pegawai dan integritas mereka dalam memenuhi misi organisasi.

Beberapa manfaat lain dari hasil pendidikan dan pelatihan yang diikuti oleh pegawai adalah (a) meningkatkan produktivitas; (b) mengurangi intensitas pengawasan; (c) meningkatkan moral kerja; dan (d) meningkatkan stabilitas organisasi. Pada gilirannya kinerja pegawai dapat ditingkatkan baik volume maupun kualitasnya. Bagi organisasi pemerintahan daerah, maka pendidikan dan pelatihan kepemimpinan sangat berguna untuk meningkatkan kinerja pegawai negeri dalam rangka mencapai misi dan tujuan. 


\section{Manfaat Diklat Dalam Peningkatan Keterampilan Kerja Pegawai}

Menurut Schermerhorn (2004) keterampilan kerja merupakan kemampuan seorang pegawai dalam menggunakan peralatan dan menyelesaikan pekerjaan dengan baik. Keterampulan ini diperoleh dari proses yang terus-menerus baik dari rutinitas dan pengalaman terhadap pekerjaan tertentu serta dari program pendidikan dan pelatihan. Oleh karena itu, agar manfaat yang diterima pegawai lebih besar lagi, jenis pendidikan dan pelatihan yang diikuti juga sangat berpengaruh, misalnya seorang operator komputer tentu saja sangat sesuai jika pelatihan yang diikuti adalah pelatihan tentang IT, penggunaan software dan sebagainya.

Lebih jauh lagi pendidikan dan pelatihan adalah upaya terprogram yang diadakan dengan tujuan untuk meningkatkan pengetahuan (knowledge), kemampuan (skills) dan pencerahan kepribadian (moral). Setiap pegawai yang mempunyai pengetahuan yang cukup, kemampuan yang tinggi, dan moral kerja yang bagus, maka tentu akan menciptakan prestasi (kinerja) yang baik (Handoko, 2008). Pelatihan dimaksudkan untuk meningkatkan kemampuan praktis dan pengetahuan teoritis yang didapatkan oleh pegawai. Pendidikan dibagi menjadi tiga, yaitu pendidikan formal, pendidikan informal, dan pendidikan nonformal. Dengan demikian dapat ditarik kesimpulan, bahwa pendidikan dan pelatihan kepemimpinan termasuk jenis pendidikan formal. Untuk menggunakan sarana dan prasarana serta peralatan kerja, pegawai terutama peralatan-peralatan kerja baru hendaknya diberikan pendidikan dan pelatihan terhadap penggunaan peralatan dan prosedur peralatan baru tersebut. Jika tidak, maka peralatan kerja baru tersebut tidak akan dapat menunjang pekerjaan pegawai dengan maksimal, malah akan menurunkan hasil kerja. Misalnya, pegawai mahir mengetik surat dengan mesik ketik, namun karena kebutuhan dan kerapian surat, peralatan mesin ketik tersebut diganti dengan perangkat komputer. Jika pegawai tersebut tidak diberi pelatihan terhadap penggunaan program komputer tersebut, maka pegawai tidak akan dapat menyelesaikan pekerjaannya, begitu juga untuk pekerjaan-pekerjaan lainnya.

\section{Manfaat Diklat Dalam Peningkatan Pemahaman Kerja Pegawai}

Pemahaman terhadap pekerjaan merupakan dampak paling akhir yang akan diperoleh pegawai setelah pegawai mengetahui dan memiliki keterampilan menyelesaikan pekerjaan. Pemahaman kerja merujuk pada tingkatan profesionalisme pegawai dalam melaksanakan tugas. Artinya, pegawai sangat mengerti pekerjaan beserta uraian-uraian tugas sehingga tidak akan mengalami kesulitan dalam melaksanakan dan menyelesaikannya.

Spencer dan Spencer (2003) menyatakan bahwa pemahaman pegawai terhadap pekerjaannya merupakan sesuatu yang konsisten yang dipikirkan dan diinginkan sehingga menyebabkan suatu tindakan yang baik dan benar. Pemahaman pegawai terhadap pekerjaan akan mendorong dan mengarahkan perilaku pada tindakan yang benar dan sesuai dengan hasil yang diharapkan.

Dengan adanya peningkatan pengetahuan dan keterampilan yang diperoleh dari hasil pendidikan dan pelatihan, akan membentuk pegawai yang memiliki pemahaman yang baik terhadap pekerjannya. Dengan pemahaman yang semakin baik, maka pegawai akan merasa pekerjaan yang dienbanya sangat ringan dan dapat diselesaikannya. 
Berdasarkan penjelasan di atas, dapat diketahui bahwa pendidikan dan pelatihan merupakan salah satu faktor di dalam pengembangan sumber daya manusia. Pendidikan dan pelatihan tidak saja menambah pengetahuan, akan tetapi juga meningkatkan keterampilan yang berakibat pada peningkatan produktivitas kerja. Pendidikan dan pelatihan sesungguhnya tidaklah sama walaupun banyak persamaannya, keduanya berhubungan dengan pemberian bantuan kepada karyawan agar karyawan tersebut dapat berkembang tingkat kecerdasannya, pengetahuan dan kemampuan yang lebih tinggi. Pendidikan bersifat lebih teoritis daripada praktis sedangkan pelatihan lebih bersifat penerapan segera dari berbagai pengetahuan dan keahlian, jadi pelatihan lebih bersifat praktis.

\section{SARAN}

Beberapa saran yang dapat dipertimbangkan oleh Badan Kepegawaian Daerah Provinsi Bengkulu dalam upaya mempertahankan dan meningkatkan kemampuan kerja pegawainya adalah:

1. Pendidikan dan pelatihan harus selalu dilakukan karena merupakan kegiatan strategis dalam peningkatan pengetahuan, keterampilan dan kemampuan pegawai dalam melaksanakan tugas-tugasnya.

2. Program pendidikan dan pelatihan disesuaikan dan berkaitan langsung dengan tugas-tugas pegawai, sehingga hasil diklat dapat diaplikasikan di tempat kerja.

3. Pembagian jadwal dan personil yang akan mengikuti program diklat secara baik dan proporsional agar terjadi pemerataan, tujuannya adalah agar pegawai memiliki kemampuan kerja yang seragam sehingga pegawai dapat memberikan pelayanan kepada masyarakat dengan baik.

\section{DAFTAR PUSTAKA}

Anoraga, Panji, 2005. Manajemen Sumber Daya Manusia. BPFE. Yogyakarta.

Atmodiwirio, Subagio. 2005. Manajemen Pendidikan Indonesia, Ardadizya Jaya. Jakarta

Bahrun, Maimun. 2007. Manajemen Kepegawaian Negara. Pusat Pendidikan dan pelatihan Pegawai. Departemen Pendidikan Nasional. Jakarta.

Cahaya. 2012. Manfaat Pendidikan Dan Pelatihan (Diklat) Dalam Peningkatan Kemampuan Pegawai (Studi Deskriptif Kualitatif Pada Pegawai BKPMD Provinsi Bengkulu. Tesis Program Pascasarjana. Bengkulu.

Dessler, Gerry, 2010. Human Resources Management, Kelompok Gramedia Pustaka Utama, Jakarta.

Gie, Kwik, Kian. 2000.Manajemen Pemerintahan, LAN. Jakarta.

Handoko, T, Hani.2008. Manajemen Personalia dan Sumber Daya Manusia, Edisi Kedua, BPFE. Yogyakarta

Hasibuan, Malayu SP. 2010. Manajemen Sumber Daya Manusia. Gunung Agung. Jakarta

Herry, Abu. 2003. Pengaruh Kemampuan, Pendidikan dan Lingkungan kerja Terhadap Pengembangan Karir Pegawai Negeri Sipil di Lingkungan Daerah Kabupaten Musi Rawas, Tesis Program MM, tidak dipublikasikan 
Hersey, P. Kenneth H. Blanchard, 2006. Management of Organization Behavior, Prentice Hall. New York.

Herwan, 2007. Pengaruh Kompetensi dan Pengalaman Kerja Terhadap Kinerja Pegawai pada Dinas Pertambangan dan Energi Kabupaten Bengkulu Utara, Tesis Program MM, tidak dipublikasikan

Kazuo, Koike. 1996. The Economic of Work in Japan, LTCB International Library Foundation, Tokyo. Japan.

Maman, S. 2002. Manajemen Sumber Daya Manusia. Alfabeta. Bandung.

Martoyo, Susilo. 2008. Manajemen Sumber Daya Manusia. Salemba Empat. Jakarta.

Mathis D., dan Jackson, R. 2006. Human Resources Management, Prenhalindo. Jakarta.

Megginson, David, 2009. Human Resources Development, PT Elex Media Komputindo. Jakarta.

Miles and Huberman. 1984. Qualitative Data Analysis: A. Sourcebook of New Methods. Sage Publication, Inc. London

Moeloeng, Lexy J. 2002. Metodologi Penelitian Kualitatif, Remadja Rosdakarya, Bandung.

Mulyasa. 2004. Menjadi Guru Profesional. PT. Remaja. Rosdakarya. Bandung

Mulyanto, 2008. Peran Persepsi Pegawai tentang Program Diklat dan Kenaikan Pangkat Pegawai terhadap Persepsi Pimpinan tentang Pengembangan Karier Bawahan, Tesis Program Pascasarjana. Surakarta.

Nasir. 2003. Metode Penelitian. Ghalia Indonesia. Jakarta.

Nasution. 2007. Metode Research: Penelitian Ilmiah. Bumi Aksara. Jakarta

Peraturan Pemerintah No 101 tahun 2000 Tentang Pendidikan dan Latihan Pegawai Negeri Sipil

Ranupandoyo, R. dan Husnan, Suad, 2010. Manajemen Sumber Daya Manusia, BPFE, Yogyakarta

Riwukaho, S. 2007. Manajemen Pelayanan Umum, Bumi Aksara, Jakarta.

Robbins, Stephen P., 2001. Perilaku Organisasi, Jilid 1, Alih Bahasa: PT Indeks, Kelompok Gramedia. Jakarta.

Robbins, Stephen P. 2003. Perilaku Organisasi, Jilid 2, Alih Bahasa: PT Indeks, Kelompok Gramedia. Jakarta.

Saprida, Meri 2010. Manfaat Pendidikan dan Pelatihan pada Peningkatan Kemampuan kerja Bidan dan Perawat pada RSUD Arga Makmur, Tesis Program MM, tidak dipubilasikan.

Sastrohadiwiryo, B, Siswanto. 2001. Manajemen Ilmu Pemerintahan. LAN. Jakarta.

Schermerhon, Jr. 2004. Managing Organizational Behavior. John Willey and Sons. New York.

Simamora, Hendry. 2005. Manajemen Sumber Daya Manusia, Edisi kedua, STIE YPKN. Yogyakarta.

Sofo, Francesco, 2009. Human Resources Development: Perspective, Roles and Practice Choices, Business and Professional Publishing, Warriewood, NSW.

Spencer, Lyle H, Jr, dan Spencer, Singe M., 2003. Competence at Work: Models for Superior Performance, Jhon Willey and Sons Inc, New York.

Suhur, Nuzwar, 2003. Analisis Pengaruh Pendidikan, Latihan dan Pengalaman Kerja Terhadap Kinerja Karyawan Pada Dinas Pendapatan Kota Bengkulu, Tesis Program MM, tidak dipublikasikan.

Sunarno, 2007. Statistika untuk penelitian. Alfabeta. Bandung

George R. Terry. 2003. Dasar-Dasar Manajemen, Bumi Aksara: Jakarata 
Yuwono, 2001. Manajemen Kinerja. Edisi Kedua. Rajawali Press. Jakarta 